\title{
Effects of Organophosphorus and Pyrethroid pesticides on antioxidant enzymes and reactivation effects of Pralidoxime: In vitro studies
}

\author{
Hatice Paluzar ${ }^{1, *}$, Ayten Sagiroglu ${ }^{2}$ \\ ${ }^{1}$ Dept. of Chemistry and Chemistry Process. Tech., Arda Vocational College \\ ${ }^{2}$ Dept. of Chemistry, Faculty of Science \\ Trakya University, Turkey \\ *Corresponding author: haticepaluzar@trakya.edu.tr
}

\begin{abstract}
The present study aimed to assess the inhibition effects of organophosphate pesticides, malathion $^{\mathrm{R}}$, dichlorvos ${ }^{\mathrm{R}}$; pyrethroid pesticides, deltamethrin ${ }^{\mathrm{R}}, \lambda$-cyhaloethrin ${ }^{\mathrm{R}}$ on antioxidant enzymes and the reactivation ability of pralidoxime against pesticide inhibited-antioxidant enzymes. Oximes were reported by reactivation ability against organophosphate inhibitedacetylcholinesterase and we focused to investigate the reactivation effect of pralidoxime against organophosphate inhibited-antioxidant enzymes. $\mathrm{IC}_{50}$ values were determined by means of activity percentage diagrams. The concentrations of deltamethrin ${ }^{\mathrm{R}}$, malathion ${ }^{\mathrm{R}}$, dichlorvos ${ }^{\mathrm{R}}, \lambda$ cyhaloethrin $^{\mathrm{R}}$ that inhibited $50 \%$ of catalase were $5.2 \mu \mathrm{M}, 158 \mu \mathrm{M}, 133 \mu \mathrm{M}, 320 \mu \mathrm{M}$, respectively, inhibited $50 \%$ of superoxide dismutase were $62 \mu \mathrm{M}, 240 \mu \mathrm{M}, 328 \mu \mathrm{M}, 2320 \mu \mathrm{M}$, respectively and inhibited $50 \%$ of glutathione peroxidase were $0.7 \mu \mathrm{M}, 1198 \mu \mathrm{M}, 1638 \mu \mathrm{M}, 98$ $\mu \mathrm{M}$, respectively. All pesticide doses showed an inhibition effect on antioxidant enzymes. Deltamethrin ${ }^{\mathrm{R}}$ was found to be a more potent inhibitor for the antioxidant enzymes followed by the rest of the pesticides used in this study. The reactivation effect of pralidoxime was determined for organophosphate inhibited-enzymes. Reactivation results showed that only catalase is reactivated by pralidoxime against dichlorvos ${ }^{\mathrm{R}}$ and malathion ${ }^{\mathrm{R}}$. Under the exposure of $50-800 \mu \mathrm{M}$ malathion ${ }^{\mathrm{R}}$ concentrations, the activities of catalase were calculated as $72-11 \%$, respectively. After, inhibited catalase was incubated with $1 \mathrm{mM}$ and $10 \mathrm{mM}$ pralidoxime, the activities of catalase were calculated as $92-31 \%$ and $98-39 \%$, respectively. Under the exposure

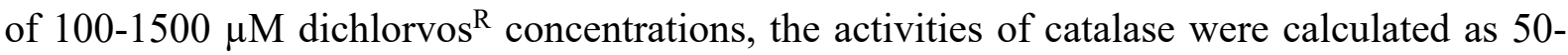
$6 \%$, respectively. After, inhibited catalase was incubated with $1 \mathrm{mM}$ and $10 \mathrm{mM}$ pralidoxime, the activities of catalase were calculated as $95-30 \%$ and $93-28 \%$, respectively. When the results are examined, it is seen that increasing the pralidoxime concentration does not significantly affect the reactivation percentage of the catalase enzyme.
\end{abstract}

Keywords: Deltamethrin; dichlorvos; $\lambda$-cyhaloethrin; malathion; pralidoxime.

\section{Introduction}

Organophosphate (OP) and pyrethroid (PYR) pesticides are among the most commonly used insecticides in agriculture, home, gardening, and veterinary applications. They replaced organochlorine insecticides due to their higher instability to environmental degradation. OPs do not stay in the environment for more than a few days or weeks, unlike organochlorines (Soares et. al. 2019; Fernandes et. al. 2018). However, these were proven far more toxic than 
organochlorines, as these inhibit the acetylcholinesterase enzyme vital to control body nerve signals beyond showing carcinogenic, genotoxic, cytotoxic, mutagenic, and immunotoxic effects in mammals (Sousa et. al. 2020). At the same time, many studies have shown that exposure to PYRs can cause adverse effects and increase the risk to human health, for example, it can be carcinogenic and mutagenic to organisms and can affect the immune system, reproductive system, and nervous system (Han et. al. 2017; Koureas et. al. 2012; Wongmaneepratip \& Yang 2020). Due to their widespread use, residues of these compounds are found in food products, water, air, and house dust (Mercier et. al. 2011; Banarjee et. al. 2012; Coscollà et. al. 2017; Gibss et. al. 2017; Tang et. al. 2018; Van der Dries et. al. 2018; Manzoor et. al. 2016), and human exposure through diet (Tsatsakis et. al. 2003; Fortes et. al. 2003; Ciscato et. al. 2014), dermal contact or inhalation (Becker et. al. 2006; McKone et. al. 2007). However, these compounds represent potential risks to the environment and human health. Many chemicals, especially pesticides, at relatively low dosages affect the metabolism of organisms by altering the activities of enzymes (Is1k et. al. 2004; Turan et. al. 2002). Looking at the widespread use of some OPs (malathion, dichlorvos) and PYRs (deltamethrin, $\lambda$ cyhalothrin) for agricultural purposes, the present study was aimed to evaluate the adverse effects of these pesticides on antioxidant enzymes namely catalase (CAT), speroxide dismutase (SOD) and glutathione peroxidase (GPx) in vitro.

On the other hand, when it comes to OP toxicity, the inhibition of acetylcholinesterase (AChE) comes to mind first. The inhibition process occurs mainly due to the formation of a P$\mathrm{O}$ bond between the electrophilic center of OPs and the oxygen atom of the active serine residue, yielding a phosphylated AChE adduct (Jokanovic 2001). Until dealkylation occurs, the reaction is usually reversible. This removal of alkyl group is known as the 'aging' process (Worek et. al. 2004). The adduct formed after aging is no longer available for reactivation. Worldwide, efforts have focused for many years on finding ways to restore the function of aged AChE (Quinn et. al. 2017). However, if a nucleophile such as oxime attacks the phosphorous atom before aging of OP-AChE adduct, it can detach the OP from the serine group, and thus the enzyme can be regenerated (Kitagawa et. al. 2019). Oxime based cholinesterase reactivators such as pralidoxime (PAM) have been used as antidotes against OP-intoxication (Worek et. al. 2020; Antonijevic et. al. 2018; Savall et. al. 2020). No study has yet been reported on the reactivation effect of PAM on OP inhibited- antioxidant enzymes. Considering the OP inhibition with the mentioned pesticides, the in vitro reactivation effect of PAM on OP inhibited-antioxidant enzymes was first time experimentally investigated in this present study.

\section{Materials and methods}

\subsection{Chemicals}

All enzymes and all other reagents were purchased from Merck KGaA. Other chemicals were prepared analytically. Superoxide dismutase (from bovine erythrocytes, $300 \mathrm{KU}$, lyophilized powder, $\geq 3.000$ units $/ \mathrm{mg}$ protein), catalase (from bovine liver, lyophilized powder, $\geq 10.000$ units/mg protein), Glutation peroksidaz (from bovine erythrocytes, $300 \mathrm{KU}$, lyophilized powder, White, $\geq 100$ units/mg), Glutathion reductase (from baker's yeast (S. cerevisiae), 2.5 
KU, ammonium sulphate suspension, 100-300 units/mg protein (biuret)), Malathion [Diethyl 2-[(dimethoxy phosphorothioyl) sulfanyl] butanedioate], dichlorvos [2,2-dichlorovinyl dimethyl phosphate], deltamethrin [(S)-Cyano-(3-phenoxyphenyl)-methyl] (1R,3R)-3-(2,2dibromoethenyl)-2,2-dimethyl-cyclopropane-1-carboxylate] and $\lambda$-cyhalothrin $[(\mathrm{R})$ - cyano (3-phenoxyphenyl) methyl] (1S, 3S)-3-[(Z)-2-chloro-3, 3, 3 - trifluoroprop - 1 - enyl]- 2, 2 dimethyl cyclopropane - 1 - carboxylate], Pralidoxime [2-pyridine aldoxime methyl chloride] were purchased form Merck KGaA. All pesticides were prepared in ethanol. The chemical structures of the pesticides and Pralidoxime (PAM) were shown at Table 1.

Table 1. Structures of investigated pesticides and pralidoxime reactivator

Malathion Dichlorvos

\subsection{Aparatus}

Ultrasonic water bath (Wise Clean DAIHAN, WUC-AO3H, Korea), microplate reader (Thermo Scientific, Type 1510, Thermo fisher scientific Oy, Rotastie 2, FI-01620, Vantaa, Finland), precision scale (Precisa XB 220A, Precisa Gravimetrics AG/Switzerland), 8-channel dispenser pipette (Eppendorff from Research Plus, from 10 to $100 \mu \mathrm{L}$ ), the dispenser pipette (Eppendorff the Multipette plus), micropipettes $(20 \mu \mathrm{L}, 200 \mu \mathrm{L}, 1000 \mu \mathrm{L}$ Eppendorff micropipette), 
circulating water bath (core IC 302, Turkey), magnetic stirrer (Biosan magnetic stirrer MSH 300) was used. Glass and disposable polypropylene or polystyrene plastics tend to absorb light in the UV range so that 96-well quartz plates were used in the UV range. For obtaining good results, using the appropriate microplate for UV region is more important (Held 2001).

\subsection{Methods}

\subsubsection{CAT activity assay: inhibition and reactivation}

CAT enzymatic activity was determined by using a method by Aebi (Aebi 1984). The principle of the assay is based on the determination of the rate constant $\left(\mathrm{s}^{-1}, \mathrm{k}\right)$ of hydrogen peroxide decomposition by CAT enzyme. $\mathrm{H}_{2} \mathrm{O}_{2}$ consumption was measured at $240 \mathrm{~nm}$ for $180 \mathrm{~s}$ using a Thermo Scientific, Type 1510 microplate reader. Quartz 96 well plates are used for the assay. CAT activity was determined using a specific absorption coefficient at $0.040 \mathrm{~cm}^{2} \mu \mathrm{mol}^{-1} \mathrm{H}_{2} \mathrm{O}_{2}$. For the preparation of Catalase solution, 26.6 U/mL of CAT (from bovine liver, lyophilized powder, $\geq 10.000$ units/mg protein) was prepared by dissolving in phosphate buffer $(50 \mathrm{mM}$, pH: 7.0). For substrate solution, approximately $9.375 \mathrm{mM}$ stock $\mathrm{H}_{2} \mathrm{O}_{2}$ solution is prepared by $50 \mathrm{mM}$ phosphate buffer (pH: 7.0). $20 \mu \mathrm{L}$ CAT enzyme solution and $200 \mu \mathrm{L} 50 \mathrm{mM}$ phosphate buffer ( $\mathrm{pH}$ : 7.0) were added to the plate. Then, $80 \mu \mathrm{L} \mathrm{H}_{2} \mathrm{O}_{2}$ stock solutions were added to the reaction medium, and absorbance was rapidly measured at this time at $240 \mathrm{~nm}\left(\mathrm{Abs}^{0}\right)$. After the quartz plate was placed into the microplate reader, absorbances were measured for $180 \mathrm{~s}$ at $240 \mathrm{~nm}\left(\mathrm{Abs}^{1}\right)$. One unit of CAT activity corresponds to the amount of enzyme, decomposing the reaction of $1 \mu \mathrm{mol} \mathrm{H}_{2} \mathrm{O}_{2}$ per 1 min.

For the inhibition assay of CAT, PYR pesticides (deltamethrin ${ }^{\mathrm{R}}, \lambda$-cyhaloethrin ${ }^{\mathrm{R}}$ ) and OP pesticides (malathion ${ }^{\mathrm{R}}$, dichlorvos ${ }^{\mathrm{R}}$ ) were used as inhibitors. $10 \mu \mathrm{L}$ of different concentrations of these pesticides were added to enzyme activity determination medium and incubated for 15 min before adding substrate solution. After $15 \mathrm{~min}, 80 \mu \mathrm{L} \mathrm{H}_{2} \mathrm{O}_{2}$ was added to the reaction medium. $\mathrm{Abs}^{0}$ and $\mathrm{Abs}^{1}$ were read, and $\mathrm{CAT}$ activities were determined for different concentrations of the pesticides. Thus, minimum and maximum pesticide concentrations that affect the activity of CAT were determined; for deltamethrin ${ }^{\mathrm{R}} 2 \mu \mathrm{M}-40 \mu \mathrm{M}$; for $\lambda$ cyhaloethrin $^{\mathrm{R}} 250 \mu \mathrm{M}-2250 \mu \mathrm{M}$; for malathion ${ }^{\mathrm{R}} 50 \mu \mathrm{M}-500 \mu \mathrm{M}$; for dichlorvos ${ }^{\mathrm{R}} 100 \mu \mathrm{M}$ $1500 \mu \mathrm{M}$. Graphs of the percent of activity versus the pesticide concentration were drawn by using these pesticide concentrations range. The values of $\mathrm{IC}_{50}$ were drawn by regression analysis graphs with a GraphPad Prism 8.0 program and calculated from activity (\%) pesticides concentration graphs. CAT activity without pesticides $(0 \mathrm{mM})$ was accepted as $100 \%$ and this measurement was called control. All the runs $(n=5)$ were carried out in specified conditions.

For reactivation assays, the activity of enzyme in the control remained constant during the experiment. Oximes were reported by reactivation ability against organophosphate inhibitedAChE (Kobrlova et. al. 2019) and in this work, we focused to investigate the reactivation effect of pralidoxime against OP inhibited - antioxidant enzymes. So that, in order to determine the 
reactivation effect of PAM, OP pesticides $\left(\right.$ malathion $^{\mathrm{R}}$, dichlorvos ${ }^{\mathrm{R}}$ ) solutions were added to the enzyme solutions and incubated for $15 \mathrm{~min}$ at $37^{\circ} \mathrm{C}$.

For the reactivation assay of CAT, the concentrations of organophosphates used were based on the concentrations determined at the inhibition assay pesticides (for malathion ${ }^{\mathrm{R}}$ between 50 $\mu \mathrm{M}-500 \mu \mathrm{M}$; for dichlorvos ${ }^{\mathrm{R}}$ between $\left.2 \mu \mathrm{M}-1500 \mu \mathrm{M}\right)$. Two different concentrations of PAM (final concentrations of tested reactivator were 1 and $10 \mathrm{mM}$ ) were used for the reactivation assay, for this, stock-PAM solutions were prepared. $10 \mu \mathrm{L}$ of stated concentrations of these pesticides were added to enzyme activity determination medium and incubated for 15 min before adding PAM solution. After $15 \mathrm{~min}, 10 \mu \mathrm{L}$ of stock-PAM solutions was added to the reaction medium and again incubated for $15 \mathrm{~min}$ at $37^{\circ} \mathrm{C} .80 \mu \mathrm{L} \mathrm{H}_{2} \mathrm{O}_{2}$ was added to the reaction medium. $\mathrm{Abs}^{0}$ and $\mathrm{Abs}^{1}$ were read. CAT activities were measured and calculated with a constant substrate and different inhibitor concentrations. The reactivation percentage of the inhibited enzyme was calculated as the ratio of the recovered enzyme activity and activity in the control. The reactivation analysis graph for CAT was drawn using activity \% values.

\subsubsection{SOD activity assay: inhibition and reactivation}

Determination of SOD enzyme activity was performed according to the method of NitroBlue Tetrazolium/Riboflavin (NBT/RF) (Cakmak and Marschner 1992). In SOD activity assay, Iodonitrotetrazolium chloride (INT) which forms a red dye in the presence of free radical was used instead of NBT. The principle of SOD activity measurement is based on the reduction of INT by $\mathrm{O}_{2}^{-}$under light and measurement, these are reduced at $560 \mathrm{~nm}$. SOD activity was assayed by measuring its ability to inhibit the photochemical reduction of INT using the method of Dhindsa (Dhindsa and Plumb-Dhindsa 1981). For the preparation of SOD solution, 379.75 $\mathrm{U} / \mathrm{mL}$ of SOD (from bovine erythrocytes, $300 \mathrm{KU}$, lyophilized powder, $\geq 3.000 \mathrm{units} / \mathrm{mg}$ protein) was prepared by dissolving in phosphate buffer (50 mM, pH: 7.0).

For activity assay, the $300 \mu \mathrm{L}$ reaction mixture contained final concentrations of $50 \mathrm{mM}$ phosphate buffer ( $\mathrm{pH}$ 7.5), $13 \mathrm{mM}$ methionine, $75 \mathrm{M}$ INT, $2 \mathrm{M}$ riboflavin, $0.1 \mathrm{mM}$ EDTA was prepared and pipetted into a plate, and absorbance was read at $560 \mathrm{~nm}\left(\mathrm{~A}^{0}\right)$. After reading $\mathrm{A}^{0}$, $15 \mu \mathrm{L}$ of SOD solution was added to this medium. The plate was shaken and placed $30 \mathrm{~cm}$ below a light bank consisting of two $15 \mathrm{~W}$ fluorescent lamps for $10 \mathrm{~min}$. The absorbance $\left(\mathrm{A}^{1}\right)$ by the reaction mixture was read at $560 \mathrm{~nm}$ using a Thermo Scientific, Type 1510 microplate reader. One unit of SOD activity represents a 50\% inhibition of the production of free radicals.

To determine the inhibition effects of pesticides on SOD activity, pyrethroid pesticides (deltamethrin $^{\mathrm{R}}, \lambda$-cyhaloethrin ${ }^{\mathrm{R}}$ ) and organophosphate pesticides (malathion ${ }^{\mathrm{R}}$, dichlorvos ${ }^{\mathrm{R}}$ ) were used as inhibitors. $10 \mu \mathrm{L}$ of different concentrations of these pesticides were added to stock SOD enzyme solution and incubated for $15 \mathrm{~min}$ before adding substrate solution. After $15 \mathrm{~min}, 15 \mu \mathrm{L}$ of SOD enzyme solution inhibited by the pesticides was added to the reaction medium. $\mathrm{Abs}^{0}$ and $\mathrm{Abs}^{1}$ were read, and SOD activities were determined for different concentrations of the pesticides. Thus, minimum and maximum pesticide concentrations that affect the activity of SOD were determined; for deltamethrin ${ }^{\mathrm{R}} 2 \mu \mathrm{M}-40 \mu \mathrm{M}$; for $\lambda$ - 
cyhaloethrin $^{\mathrm{R}} 250 \mu \mathrm{M}-2250 \mu \mathrm{M}$; for malathion ${ }^{\mathrm{R}} 50 \mu \mathrm{M}-500 \mu \mathrm{M}$; for dichlorvos ${ }^{\mathrm{R}} 100 \mu \mathrm{M}$ $1500 \mu \mathrm{M}$. Graphs of the percent of activity versus the pesticide concentration were drawn by using these pesticide concentrations range. The values of $\mathrm{IC}_{50}$ were drawn by regression analysis graphs with a GraphPad Prism 8.0 program and calculated from activity (\%) pesticides concentration graphs. SOD activity without pesticides $(0 \mathrm{mM})$ was accepted as $100 \%$ and this measurement was called control. All the runs $(n=5)$ were carried out in specified conditions.

For reactivation assays, only organopohosphate inhibited - SOD enzymes were examined (organopohosphate pesticides; malathion ${ }^{\mathrm{R}}$, and dichlorvos ${ }^{\mathrm{R}}$ ). For the reactivation assay of SOD, the concentrations of organophosphates used were based on the concentrations determined at the inhibition assay pesticides (for malathion ${ }^{\mathrm{R}}$ between $50 \mu \mathrm{M}-500 \mu \mathrm{M}$; for dichlorvos ${ }^{\mathrm{R}}$ between $100 \mu \mathrm{M}-1500 \mu \mathrm{M}$ ). Two different concentrations of PAM (final concentrations of the tested reactivator were 1 and $10 \mathrm{mM}$ ) were used for the reactivation assay. For this, stockPAM solutions were prepared. $10 \mu \mathrm{L}$ of stated concentrations of these pesticides were added to stock SOD solution and incubated for $15 \mathrm{~min}$ before adding PAM solution. After $15 \mathrm{~min}, 10$ $\mu \mathrm{L}$ of stock-PAM solutions was added to the inhibited SOD solutions and again incubated for $15 \mathrm{~min}$ at $37^{\circ} \mathrm{C} .15 \mu \mathrm{L}$ of SOD enzyme solution inhibited by the pesticides and reactivated by PAM added to the reaction medium for determination of the activity. $\mathrm{Abs}^{0}$ and $\mathrm{Abs}^{1}$ were read. SOD activities were measured and calculated with a constant substrate and different inhibitor concentrations. The reactivation percentage of the inhibited enzyme was calculated as the ratio of the recovered enzyme activity and activity in the control. Reactivation analysis graph for SOD was drawn using activity \% values.

\subsubsection{GPx activity assay: inhibition and reactivation}

The enzymatic activity of GPx was measured by Beutler's method (Beutler 1971). The assay recording of NADPH loss measures $\mathrm{H}_{2} \mathrm{O}_{2}$ reduction by GPx to alcohol at $340 \mathrm{~nm}$ (Christine and Joseph 2010). To determine the GPx activity within a sample, given that 1 unit $=1 \mu$ mole NADPH oxidized $\min ^{-1}$ at the specified GSH concentrations or more correctly, $\mu$ moles GSH produced $\mathrm{min}^{-1}$. For the preparation of GPx solution, $0.5 \mathrm{U} / \mathrm{mL}$ of GPx (from bovine erythrocytes, $300 \mathrm{KU}$, lyophilized powder, White, $\geq 100$ units/mg), was prepared by dissolving in phosphate buffer (50 mM, pH: 7.0).

GPx activity was assayed by measuring the decrease in absorbance at $340 \mathrm{~nm}$ due to the oxidation of NADPH. The $300 \mu \mathrm{L}$ reaction mixture contained final concentrations of $0.1 \mathrm{M}$ Tris- $\mathrm{HCl}$ (pH 8.0), $1 \mathrm{mM}$ EDTA, $0.1 \mathrm{mM}$ NADPH, and 1mM GSSG was prepared and pipetted into a quartz plate and absorbance was read at $340 \mathrm{~nm}\left(\mathrm{~A}^{0}\right)$ at $30^{\circ} \mathrm{C}$. After reading absorbance, $15 \mu \mathrm{L}$ of enzyme solution was added to this medium and after the incubation time ( $1 \mathrm{~min}$ ), absorbances were read by using Thermo Scientific, Type 1510 microplate reader. Quartz 96 well plates are used for the assay. One enzyme unit was defined as the enzyme amount reducing $1 \mu$ mole $\mathrm{NADP}^{+}$per 1 min at optimum $\mathrm{pH}$. 
For inhibition assays of GPx, pyrethroid pesticides (deltamethrin ${ }^{\mathrm{R}}, \lambda$-cyhaloethrin ${ }^{\mathrm{R}}$ ) and organophosphate pesticides (malathion ${ }^{\mathrm{R}}$, dichlorvos ${ }^{\mathrm{R}}$ ) were used as inhibitors. $10 \mu \mathrm{L}$ of different concentrations of these pesticides were added to stock GPx enzyme solution and incubated for 15 min before adding substrate solution. After 15 min, $15 \mu \mathrm{L}$ of GPx enzyme solution inhibited by the pesticides was added to the reaction medium. $\mathrm{Abs}^{0}$ and $\mathrm{Abs}^{1}$ were read, and GPx activities were determined for different concentrations of the pesticides. Thus, minimum and maximum pesticide concentrations that affect the activity of GPx were determined; for deltamethrin ${ }^{\mathrm{R}} 2 \mu \mathrm{M}-40 \mu \mathrm{M}$; for $\lambda$-cyhaloethrin ${ }^{\mathrm{R}} 250 \mu \mathrm{M}-2250 \mu \mathrm{M}$; for malathion $^{\mathrm{R}} 50 \mu \mathrm{M}-500 \mu \mathrm{M}$; for dichlorvos ${ }^{\mathrm{R}} 100 \mu \mathrm{M}-1500 \mu \mathrm{M}$. Graphs of the percent of activity versus the pesticide concentration were drawn by using these pesticide concentrations range. The values of $\mathrm{IC}_{50}$ were drawn by regression analysis graphs with a GraphPad Prism 8.0 program and calculated from activity (\%) - pesticides concentration graphs. GPx activity without pesticides $(0 \mathrm{mM})$ was accepted as $100 \%$ and this measurement was called control. All the runs $(n=5)$ were carried out in specified conditions.

For reactivation assays, only organopohosphate inhibited - GPx enzymes were examined (organopohosphate pesticides; malathion ${ }^{\mathrm{R}}$ and dichlorvos ${ }^{\mathrm{R}}$ ). For the reactivation assay of GPx, the concentrations of organophosphates used were based on the concentrations determined at the inhibition assay pesticides (for malathion ${ }^{\mathrm{R}}$ between $50 \mu \mathrm{M}-500 \mu \mathrm{M}$; for dichlorvos ${ }^{\mathrm{R}}$ between $2 \mu \mathrm{M}-1500 \mu \mathrm{M}$ ). Two different concentrations of PAM (final concentrations of the tested reactivator were 1 and $10 \mathrm{mM}$ ) were used for the reactivation assay. For this, stock-PAM solutions were prepared. $10 \mu \mathrm{L}$ of stated concentrations of these pesticides were added to stock GPx solution and incubated for 15 min before adding PAM solution. After 15 min, $10 \mu \mathrm{L}$ of stock-PAM solutions was added to the inhibited GPx solutions and again incubated for $15 \mathrm{~min}$ at $30^{\circ} \mathrm{C} .15 \mu \mathrm{L}$ of GPx enzyme solution inhibited by the pesticides and reactivated by PAM added to the reaction medium for determination of the activity. $\mathrm{Abs}^{0}$ and $\mathrm{Abs}^{1}$ were read. GPx activities were measured and calculated with a constant substrate and different inhibitor concentrations. The reactivation percentage of the inhibited enzyme was calculated as the ratio of the recovered enzyme activity and activity in the control. Reactivation analysis graph for GPx was drawn using activity \% values.

\subsubsection{Total protein assay}

The protein concentration was measured spectrophotometrically at $750 \mathrm{~nm}$ by the method of Lowry (Lowry et. al. 1951). Bovine serum albumin was used as a standard for the determination of protein concentration. For this purpose, four solutions were prepared: 1. Solution (A): $0.5 \mathrm{~g}$ $\mathrm{CuSO}_{4} .5 \mathrm{H}_{2} \mathrm{O}$ and $1 \mathrm{~g}$ sodium citrate dehydrate were dissolved in distilled water and completed to $100 \mathrm{ml} ; 2$. Solution (B): $20 \mathrm{~g} \mathrm{Na}_{2} \mathrm{CO}_{3}$ and $4 \mathrm{~g} \mathrm{NaOH}$ was dissolved in distilled water and completed to $1000 \mathrm{ml}$; 3. Solution (C): $1 \mathrm{ml}$ solution A was added to $50 \mathrm{ml}$ solution $\mathrm{B} ; 4$. Solution (D): $10 \mathrm{ml}$ Folin Ciocalteu was added to $10 \mathrm{ml}$ distilled water. After that, $2.5 \mathrm{ml}$ solution $\mathrm{C}$ was added to $0.5 \mathrm{ml}$ of prepared sample solution, vortexed, waited for 10 minutes at room temperature, mixed with $0.25 \mathrm{ml}$ solution $\mathrm{D}$, vortexed, waited for 30 minutes, and read at $750 \mathrm{~nm}$ for protein concentration determination. 


\subsubsection{Statistical analysis}

Experimental data are presented as mean \pm standard deviation (mean $\pm \mathrm{SD}$ ). The direct linear plot method was used for the determination of the kinetic constants of enzyme reactions (Eisenthal and Cornish 1974), for that the GraphPad prism software version 8 (GraphPad Inc. La Jolla, CA, USA) was used. IC $_{50}$ values were obtained when the fitting was made by a nonlinear least-squares method (Snedecor and Cochran 1980). For the statistical analyses, ANOVA (one-way analysis of variance) was used, followed by the Student Newman-Keul's test using the SPSS version 21 statistical software (SPSS Inc., Chicago, IL, USA). Differences were considered significant if $\mathrm{p}<0.05$.

\section{Results}

\subsection{Effect of organophosphate and pyrethroid pesticides on CAT Activity}

Different pesticide concentrations with CAT enzyme solutions were prepared, then, the activities of CAT were measured. Minimum and maximum pesticide concentrations that affect the activity of CAT were determined; for deltamethrin ${ }^{\mathrm{R}} 2 \mu \mathrm{M}-40 \mu \mathrm{M}$; for $\lambda$-cyhaloethrin ${ }^{\mathrm{R}} 250$ $\mu \mathrm{M}-2250 \mu \mathrm{M}$; for malathion ${ }^{\mathrm{R}} 50 \mu \mathrm{M}-500 \mu \mathrm{M}$; for dichlorvos ${ }^{\mathrm{R}} 100 \mu \mathrm{M}-1500 \mu \mathrm{M}$. Graphs of the percent of activity versus the pesticide concentration were drawn by using these pesticide concentrations range and are shown in Figure 1. Under the exposure of 50, 100, 200, 400, 600 and $800 \mu \mathrm{M}$ malathion concentrations, CAT activity $\%$ were calculated as $72 ; 63 ; 38 ; 10 ; 12$ and $11 \%$, respectively. Under the exposure of 100, 200, 400, 1000, 1200 and $1500 \mu \mathrm{M}$ dichlorvos concentrations, \% CAT activity were calculated as $50 ; 38 ; 22 ; 8 ; 7$ and $6 \%$, respectively. Under the exposure of $2,4,8,20,30$ and $40 \mu \mathrm{M}$ deltamethrin concentrations, CAT activity $\%$ were calculated as $80 ; 72 ; 56 ; 20 ; 22$ and $18 \%$, respectively. Under the exposure of $250,500,1200,1500,2000$ and $2500 \mu \mathrm{M} \lambda$-cyhaloethrin concentrations, CAT activity \% were calculated as $70 ; 55 ; 36 ; 24 ; 22$ and $23 \%$, respectively. Compared to the control activity, there are statistical differences between all CAT activities which interacted with all pesticides $(\mathrm{p}<0.05, \mathrm{n}=5)$ (Table 2). The percentages of both CAT activities were decreased under the exposure of determined concentrations of malathion, dichlorvos, deltametrhrin, and $\lambda$ cyhaloethrin. But, decreasing CAT activity with dichlorvos and malathion (OP pesticides) was higher compared to deltamethrin and $\lambda$-cyhaloethrin (PYR pesticides). However, it is also seen that deltamethrin, which is a pyrethroid class pesticide, has high inhibition \% even at very low concentrations. $\mathrm{IC}_{50}$ values (the most suitable parameters for seeing inhibitory effects) of these pesticides for CAT were determined and shown in Table 2. The $\mathrm{IC}_{50}$ values of deltamethrin, malathion, dichlorvos and $\lambda$-cyhalothrin for CAT were found as $5.2 \mu \mathrm{M}, 158 \mu \mathrm{M}, 133 \mu \mathrm{M}$, and $320 \mu \mathrm{M}$, respectively. 


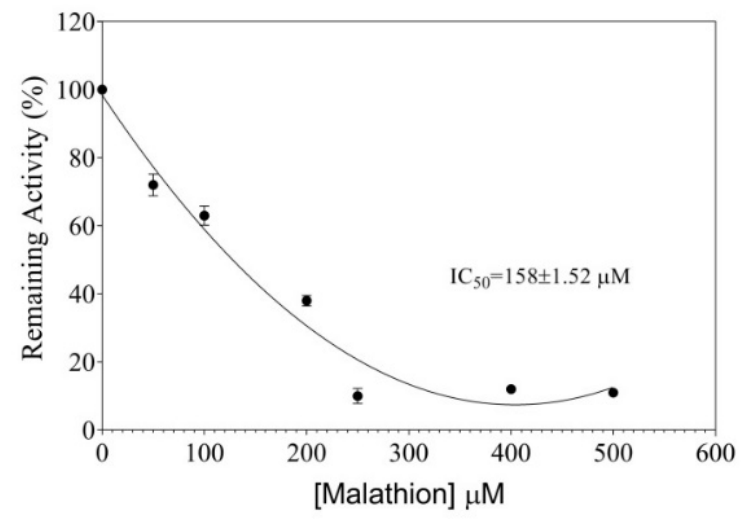

(A)

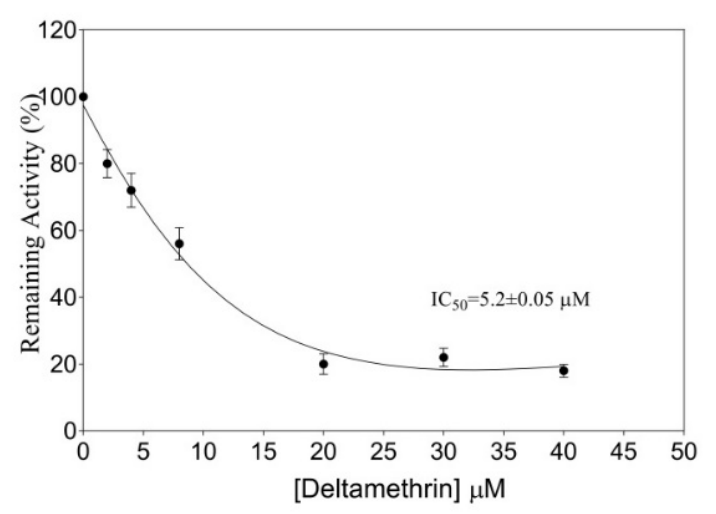

(C)

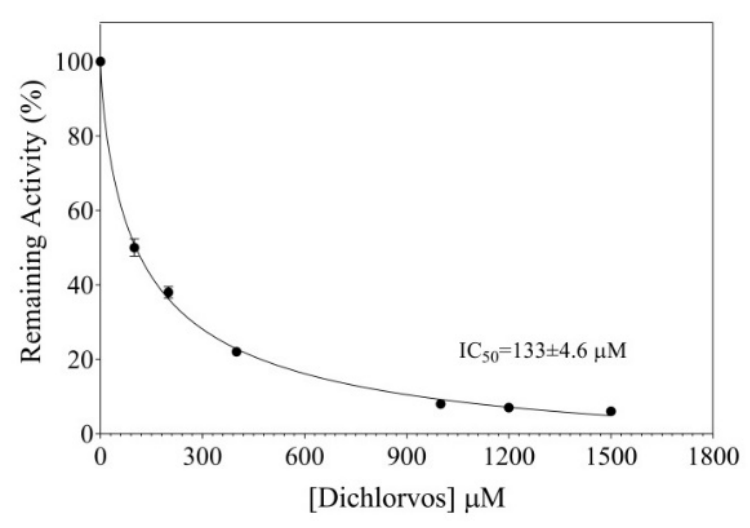

(B)

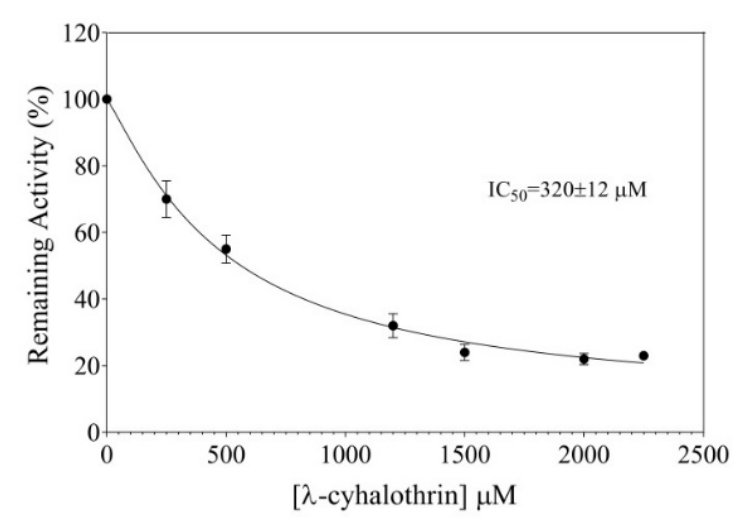

(D)

Fig. 1. The activity of catalase in the presence of various concentrations of malathion (A) and dichlorvos (B), deltamethrin (C), and $\lambda$-cyhalothrin (D). $\mathrm{IC}_{50}$ values were determined from these graphs. $(n=5)$

\subsection{Effect of organophosphate and pyrethroid pesticides on SOD Activity}

Inhibitory effects of malathion, dichlorvos, deltamethrin, $\lambda$-cyhalothrin pesticides were examined on SOD enzyme activity. For this purpose, firstly, activity assays in varying concentrations of inhibitors were done and half-maximal inhibitory concentrations $\left(\mathrm{IC}_{50}\right)$ were calculated by drawing [I]-\% activity graphs. The maximum enzyme activity of SOD was assumed to be $100 \%$ and the inhibition activity of SOD was assumed to be $0 \%$ in the absence of any pesticide. Different pesticide concentrations with SOD enzyme solutions were prepared, then, activities of SOD were measured. Minimum and maximum pesticide concentrations that affect the activity of SOD were determined; for deltamethrin ${ }^{\mathrm{R}} 2 \mu \mathrm{M}-40 \mu \mathrm{M}$; for $\lambda$ cyhaloethrin $^{\mathrm{R}} 250 \mu \mathrm{M}-2250 \mu \mathrm{M}$; for malathion ${ }^{\mathrm{R}} 50 \mu \mathrm{M}-500 \mu \mathrm{M}$; for dichlorvos ${ }^{\mathrm{R}} 100 \mu \mathrm{M}$ $1500 \mu \mathrm{M}$. Graphs of the percent of activity versus the pesticide concentration were drawn by using these pesticide concentrations range and are shown in Figure 2. Under the exposure of $50,100,200,400,600$ and $800 \mu \mathrm{M}$ malathion concentrations, SOD activity \% were calculated as $82 ; 76 ; 61 ; 37 ; 38$ and $36 \%$, respectively. Under the exposure of 100, 200, 400, 1000, 1200 and $1500 \mu \mathrm{M}$ dichlorvos concentrations, SOD activity $\%$ were calculated as $78 ; 62 ; 42 ; 42 ; 43$ 
and $41 \%$, respectively. Under the exposure of $2,4,8,20,30$ and $40 \mu \mathrm{M}$ deltamethrin concentrations, SOD activity $\%$ were calculated as $98 ; 85 ; 70 ; 62 ; 61$ and $60 \%$, respectively. Under the exposure of 250,500,1200,1500, 2000 and $2500 \mu \mathrm{M} \lambda$-cyhaloethrin concentrations, SOD activity $\%$ were calculated as $90 ; 78 ; 57 ; 55 ; 54$ and $53 \%$, respectively.

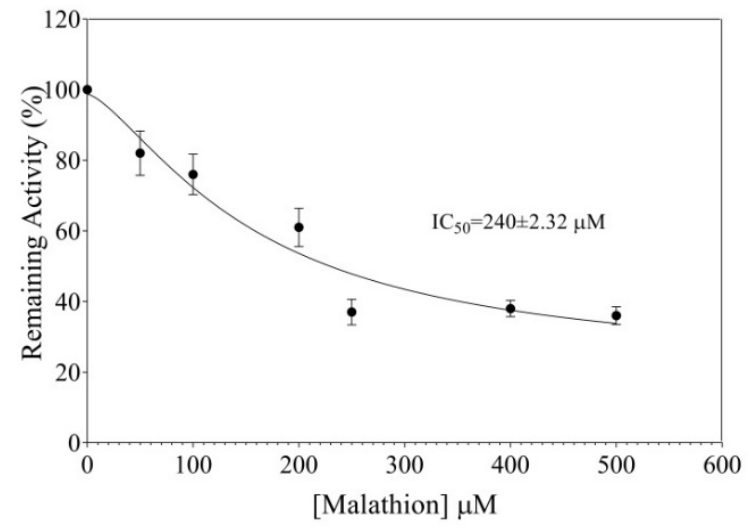

(A)

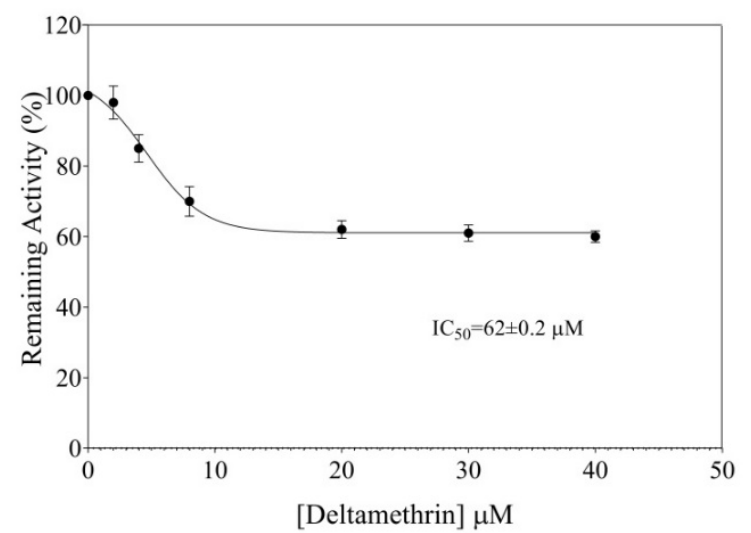

(C)

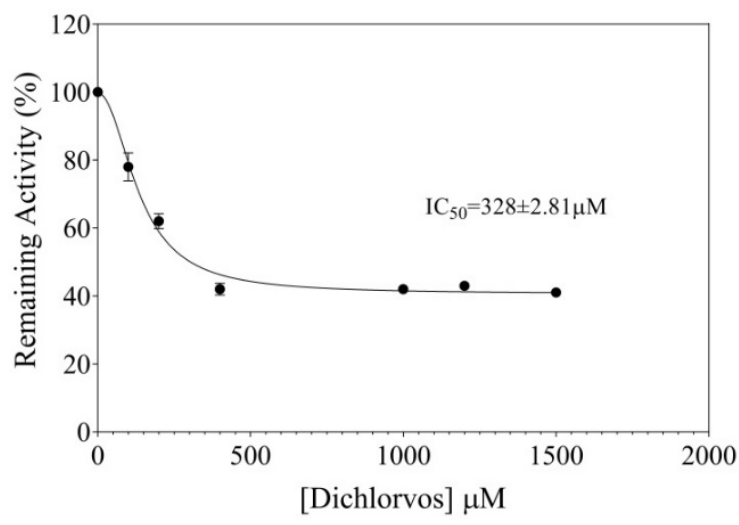

(B)

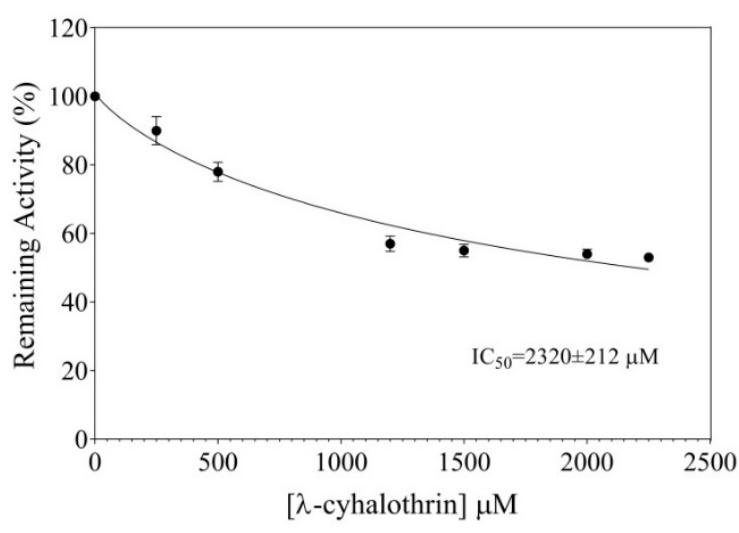

(D)

Fig. 2. The activity of superoxide dismutase in the presence of various concentrations of malathion (A) and dichlorvos (B), deltamethrin (C), and $\lambda$-cyhalothrin (D). $\mathrm{IC}_{50}$ values were determined from these graphs. $(n=5)$

Compared to the control activity, there are statistical differences between all SOD activities which interacted with all pesticides $(\mathrm{p}<0.05, \mathrm{n}=5)$ (Table 2$)$. The percentages of both SOD activities were decreased under the exposure of determining concentrations of malathion, dichlorvos, deltamethrin, and $\lambda$-cyhaloethrin. But, decreasing SOD activity with dichlorvos and malathion (OP pesticides) was higher compared to deltametrhrin and $\lambda$-cyhaloethrin (PYR pesticides). However, it is also seen that deltamethrin, which is a pyrethroid class pesticide, has high inhibition $\%$ even at very low concentrations. $\mathrm{IC}_{50}$ values (the most suitable parameters for seeing inhibitory effects) of these pesticides for SOD were determined and shown in Table 2. The $\mathrm{IC}_{50}$ values of deltamethrin, malathion, dichlorvos, and $\lambda$-cyhalothrin for SOD were found as $62 \mu \mathrm{M}, 240 \mu \mathrm{M}, 328 \mu \mathrm{M}$, and $2320 \mu \mathrm{M}$, respectively. 
Table 2. Effect of malathion, dichlorvos, deltamethrin, and $\lambda$-cyhalothrin concentrations on CAT, SOD, and GPx activity. (Differences were considered significant if $\mathrm{p}<0.05$ )

\section{Percentage of remaining activity \pm SD}

\begin{tabular}{|c|c|c|c|c|c|}
\hline Pesticides & [pesticide] $\mu \mathrm{M}$ & CAT & SOD & GPx & $\mathbf{p}$ \\
\hline \multirow[t]{7}{*}{ Malathion } & 50 & $72 \pm 3.2$ & $82 \pm 6.3$ & $95 \pm 5.4$ & $<0.05$ \\
\hline & 100 & $63 \pm 2.8$ & $76 \pm 5.7$ & $90 \pm 4.3$ & $<0.05$ \\
\hline & 200 & $38 \pm 1.5$ & $61 \pm 5.4$ & $88 \pm 2.7$ & $<0.05$ \\
\hline & 250 & $10 \pm 2.2$ & $37 \pm 3.6$ & $86 \pm 3.8$ & $<0.05$ \\
\hline & 400 & $12 \pm 0.8$ & $38 \pm 2.3$ & $85 \pm 3.4$ & $<0.05$ \\
\hline & 500 & $11 \pm 1.3$ & $36 \pm 2.5$ & $87 \pm 3.1$ & $<0.05$ \\
\hline & & $<0.05$ & $<0.05$ & $<0.05$ & $\mathbf{p}$ \\
\hline \multirow[t]{7}{*}{ Dichlorvos } & 100 & $50 \pm 2.3$ & $78 \pm 4.1$ & $98 \pm 4.5$ & $<0.05$ \\
\hline & 200 & $38 \pm 1.5$ & $62 \pm 2.2$ & $96 \pm 5.3$ & $<0.05$ \\
\hline & 400 & $22 \pm 1.2$ & $42 \pm 1.7$ & $85 \pm 5.1$ & $<0.05$ \\
\hline & 1000 & $8 \pm 0.4$ & $42 \pm 1.2$ & $83 \pm 3.4$ & $<0.05$ \\
\hline & 1200 & $7 \pm 0.2$ & $43 \pm 1.3$ & $85 \pm 3.2$ & $<0.05$ \\
\hline & 1500 & $6 \pm 0.5$ & $41 \pm 0.9$ & $84 \pm 2.7$ & $<0.05$ \\
\hline & & $<0.05$ & $<0.05$ & $<0.05$ & $\mathbf{p}$ \\
\hline \multirow[t]{7}{*}{ Deltamethrin } & 2 & $80 \pm 4.2$ & $98 \pm 4.7$ & $18 \pm 1.2$ & $<0.05$ \\
\hline & 4 & $72 \pm 5.1$ & $85 \pm 3.9$ & $16 \pm 0.7$ & $<0.05$ \\
\hline & 8 & $56 \pm 4.8$ & $70 \pm 4.2$ & $17 \pm 0.9$ & $<0.05$ \\
\hline & 20 & $20 \pm 3.1$ & $62 \pm 2.5$ & $15 \pm 1.2$ & $<0.05$ \\
\hline & 30 & $22 \pm 2.7$ & $61 \pm 2.3$ & $14 \pm 0.7$ & $<0.05$ \\
\hline & 40 & $18 \pm 1.9$ & $60 \pm 1.6$ & $13 \pm 1.3$ & $<0.05$ \\
\hline & & $<0.05$ & $<0.05$ & $<0.05$ & $\mathbf{p}$ \\
\hline \multirow[t]{7}{*}{$\lambda$-cyhalothrin } & 250 & $70 \pm 5.5$ & $90 \pm 4.1$ & $22 \pm 1.7$ & $<0.05$ \\
\hline & 500 & $55 \pm 4.2$ & $78 \pm 2.8$ & $20 \pm 1.4$ & $<0.05$ \\
\hline & 1200 & $32 \pm 3.6$ & $57 \pm 2.2$ & $18 \pm 0.6$ & $<0.05$ \\
\hline & 1500 & $24 \pm 2.4$ & $55 \pm 1.8$ & $16 \pm 0.4$ & $<0.05$ \\
\hline & 2000 & $22 \pm 1.7$ & $54 \pm 1.4$ & $17 \pm 1.7$ & $<0.05$ \\
\hline & 2250 & $23 \pm 1.1$ & $53 \pm 0.5$ & $16 \pm 0.2$ & $<0.05$ \\
\hline & & $<0.05$ & $<0.05$ & $<0.05$ & $\mathbf{p}$ \\
\hline
\end{tabular}

Table 3. Concentrations of the pesticides caused to 50\% inhibition of CAT, SOD, and GPx activity

\begin{tabular}{cccc}
\hline & \multicolumn{3}{c}{ IC $_{\mathbf{5 0}}(\boldsymbol{\mu M}) \pm$ SD } \\
\cline { 2 - 4 } PESTICIDES & $\mathbf{C A T}$ & $\mathbf{S O D}$ & $\mathbf{G P x}$ \\
\hline Deltamethrin & $5.2 \pm 0.05$ & $62 \pm 0.2$ & $0.7 \pm 0.06$ \\
\hline $\boldsymbol{\lambda}$-cyhalothrin & $320 \pm 12$ & $2320 \pm 212$ & $98 \pm 2.1$ \\
\hline Malathion & $158 \pm 1.52$ & $240 \pm 2.32$ & $1198 \pm 118$ \\
\hline Dichlorvos & $133 \pm 4.6$ & $328 \pm 2.81$ & $1638 \pm 17$ \\
\hline
\end{tabular}


Table 4. Effect of PAM on pesticide inhibited - CAT, SOD, and GPx activity.

Percentage of remaining activity \pm SD

\begin{tabular}{|c|c|c|c|c|c|}
\hline & Pesticides & $\begin{array}{c}\text { [pesticide] } \\
\mu \mathrm{M}\end{array}$ & $\begin{array}{c}\text { After being } \\
\text { inhibited by } \\
\text { pesticide }\end{array}$ & $\begin{array}{c}\text { After reactivated } \\
\text { by } 1 \text { mM PAM }\end{array}$ & $\begin{array}{c}\text { After reactivated } \\
\text { by } 10 \mathrm{mM} \text { PAM }\end{array}$ \\
\hline \multirow{12}{*}{ 妾 } & \multirow{6}{*}{ Malathion } & 50 & $72 \pm 3.2$ & $92 \pm 4.3$ & $98 \pm 5.2$ \\
\hline & & 100 & $63 \pm 2.8$ & $78 \pm 3.1$ & $89 \pm 4.3$ \\
\hline & & 200 & $38 \pm 1.5$ & $58 \pm 2.7$ & $72 \pm 2.8$ \\
\hline & & 250 & $10 \pm 2.2$ & $40 \pm 2.1$ & $57 \pm 1.7$ \\
\hline & & 400 & $12 \pm 0.8$ & $35 \pm 1.8$ & $45 \pm 1.1$ \\
\hline & & 500 & $11 \pm 1.3$ & $31 \pm 2.4$ & $39 \pm 0.9$ \\
\hline & \multirow[t]{6}{*}{ Dichlorvos } & 100 & $50 \pm 2.3$ & $95 \pm 2.7$ & $93 \pm 3.7$ \\
\hline & & 200 & $38 \pm 1.5$ & $89 \pm 3.5$ & $90 \pm 3.9$ \\
\hline & & 400 & $22 \pm 1.2$ & $62 \pm 2.4$ & $65 \pm 3.1$ \\
\hline & & 1000 & $8 \pm 0.4$ & $40 \pm 1.9$ & $43 \pm 1.2$ \\
\hline & & 1200 & $7 \pm 0.2$ & $35 \pm 1.7$ & $32 \pm 0.1$ \\
\hline & & 1500 & $6 \pm 0.5$ & $30 \pm 1.3$ & $28 \pm 1.4$ \\
\hline \multirow{12}{*}{ )ิ } & \multirow[t]{6}{*}{ Malathion } & 50 & $82 \pm 6.3$ & $83 \pm 5.1$ & $81 \pm 4.2$ \\
\hline & & 100 & $76 \pm 5.7$ & $74 \pm 4.2$ & $76 \pm 4.7$ \\
\hline & & 200 & $61 \pm 5.4$ & $63 \pm 4.7$ & $63 \pm 5.1$ \\
\hline & & 250 & $37 \pm 3.6$ & $38 \pm 3.2$ & $35 \pm 3.8$ \\
\hline & & 400 & $38 \pm 2.3$ & $34 \pm 2.1$ & $37 \pm 3.2$ \\
\hline & & 500 & $36 \pm 2.5$ & $35 \pm 1.8$ & $35 \pm 2.7$ \\
\hline & \multirow[t]{6}{*}{ Dichlorvos } & 100 & $78 \pm 4.1$ & $76 \pm 3.7$ & $74 \pm 3.1$ \\
\hline & & 200 & $62 \pm 2.2$ & $60 \pm 0.9$ & $65 \pm 2.0$ \\
\hline & & 400 & $42 \pm 1.7$ & $43 \pm 1.1$ & $40 \pm 1.3$ \\
\hline & & 1000 & $42 \pm 1.2$ & $43 \pm 1.5$ & $40 \pm 0.7$ \\
\hline & & 1200 & $43 \pm 1.3$ & $41 \pm 0.7$ & $43 \pm 0.9$ \\
\hline & & 1500 & $41 \pm 0.9$ & $43 \pm 1.4$ & $41 \pm 1.2$ \\
\hline \multirow{12}{*}{$\frac{1}{0}$} & \multirow[t]{6}{*}{ Malathion } & 50 & $95 \pm 5.4$ & $93 \pm 5.1$ & $97 \pm 4.3$ \\
\hline & & 100 & $90 \pm 4.3$ & $91 \pm 3.7$ & $89 \pm 4.1$ \\
\hline & & 200 & $88 \pm 2.7$ & $87 \pm 2.2$ & $90 \pm 3.3$ \\
\hline & & 250 & $86 \pm 3.8$ & $86 \pm 4.1$ & $85 \pm 3.5$ \\
\hline & & 400 & $85 \pm 3.4$ & $86 \pm 4.4$ & $86 \pm 3.2$ \\
\hline & & 500 & $87 \pm 3.1$ & $86 \pm 3.8$ & $86 \pm 2.7$ \\
\hline & \multirow[t]{6}{*}{ Dichlorvos } & 100 & $98 \pm 4.5$ & $96 \pm 2.3$ & $95 \pm 4.1$ \\
\hline & & 200 & $96 \pm 5.3$ & $98 \pm 4.7$ & $96 \pm 4.2$ \\
\hline & & 400 & $85 \pm 5.1$ & $83 \pm 5.5$ & $82 \pm 4.8$ \\
\hline & & 1000 & $83 \pm 3.4$ & $83 \pm 2.8$ & $85 \pm 2.3$ \\
\hline & & 1200 & $85 \pm 3.2$ & $82 \pm 2.2$ & $83 \pm 1.8$ \\
\hline & & 1500 & $84 \pm 2.7$ & $86 \pm 1.9$ & $86 \pm 1.2$ \\
\hline
\end{tabular}

\subsection{Effect of organophosphate and pyrethroid pesticides on GPx Activity}

GPx activity assays in varying concentrations of pesticides were done and the values of $\mathrm{IC}_{50}$ were calculated by drawing [I]-\% activity graphs. GPx activity without pesticides was accepted as $100 \%$ activity. Different pesticide concentrations with GPx enzyme solutions were prepared, 
then, activities of GPx were measured. Minimum and maximum pesticide concentrations that affect the activity of GPx were determined; for deltamethrin ${ }^{\mathrm{R}} 2 \mu \mathrm{M}-40 \mu \mathrm{M}$; for $\lambda$ cyhaloethrin $^{\mathrm{R}} 250 \mu \mathrm{M}-2250 \mu \mathrm{M}$; for malathion ${ }^{\mathrm{R}} 50 \mu \mathrm{M}-500 \mu \mathrm{M}$; for dichlorvos ${ }^{\mathrm{R}} 100 \mu \mathrm{M}$ $1500 \mu \mathrm{M}$. Graphs of the percent of activity versus the pesticide concentration were drawn by using these pesticide concentrations range and are shown in Figure 3. Under the exposure of 50, 100, 200, 400, 600 and $800 \mu \mathrm{M}$ malathion concentrations, GPx activity \% were calculated as $95 ; 90 ; 88 ; 86 ; 85$ and $87 \%$, respectively. Under the exposure of $100,200,400,1000,1200$ and $1500 \mu \mathrm{M}$ dichlorvos concentrations, GPx activity \% were calculated as $98 ; 96 ; 85 ; 83 ; 85$ and $84 \%$, respectively. Under the exposure of $2,4,8,20,30$ and $40 \mu \mathrm{M}$ deltamethrin concentrations, GPx activity \% were calculated as $18 ; 16 ; 17 ; 15 ; 14$ and $13 \%$, respectively. Under the exposure of 250, 500, 1200,1500, 2000 and $2500 \mu \mathrm{M} \lambda$-cyhaloethrin concentrations, $\%$ GPx activity were calculated as $22 ; 20 ; 18 ; 16 ; 17$ and $16 \%$, respectively. Compared to the control activity, there are statistical differences between all GPx activities which interacted with all pesticides $(\mathrm{p}<0.05, \mathrm{n}=5)$ (Table 2). The percentages of both GPx activities were decreased under the exposure of determining concentrations of malathion, dichlorvos, deltamethrin, and $\lambda$-cyhaloethrin. But, decreasing GPx activity with deltametrhrin and $\lambda$-cyhaloethrin (PYR class pesticides) were higher compared to dichlorvos and malathion (OP pesticides). However, it is also seen that deltamethrin, which is a pyrethroid class pesticide, has high inhibition $\%$ even at very low concentrations. $\mathrm{IC}_{50}$ values (the most suitable parameters for seeing inhibitory effects) of these pesticides for GPx were determined and shown in Table 2. The $\mathrm{IC}_{50}$ values of deltamethrin, dichlorvos, malathion, and $\lambda$-cyhalothrin for GPx were found as $0.7 \mu \mathrm{M}, 1198$ $\mu \mathrm{M}, 1638 \mu \mathrm{M}$, and $98 \mu \mathrm{M}$, respectively.

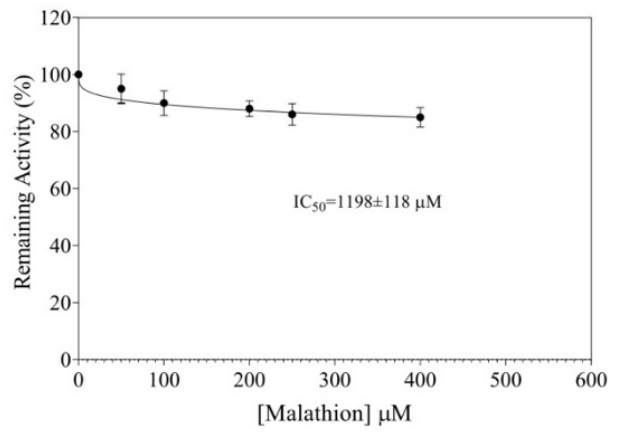

(A)

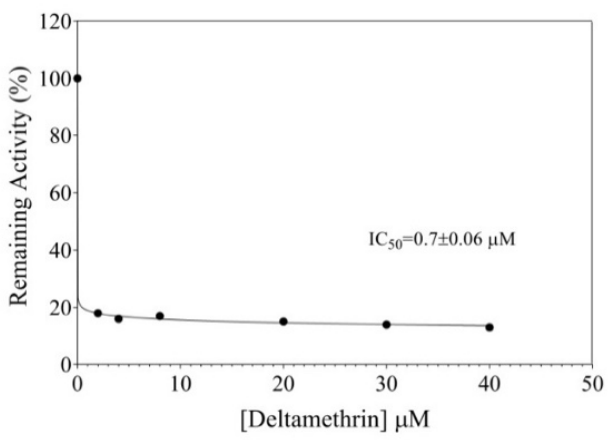

(C)

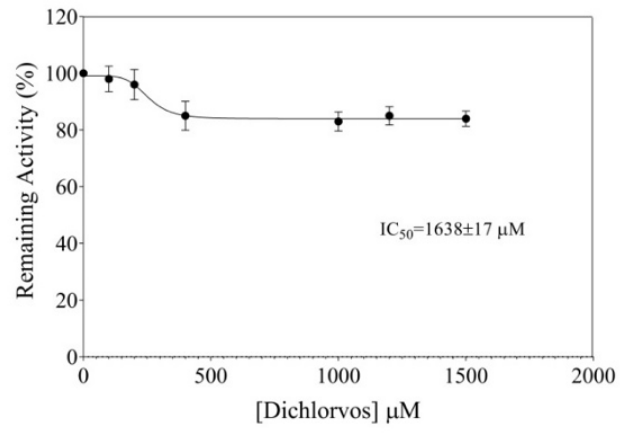

(B)

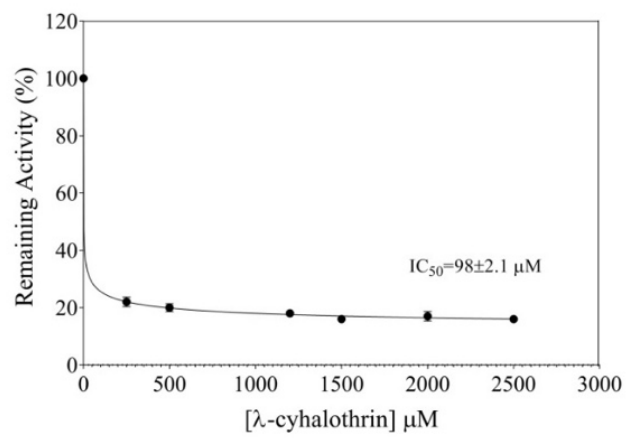

(D)

Fig. 3. The activity of glutation peroxidase in the presence of various concentrations of malathion (A) and dichlorvos (B), deltamethrin (C), and $\lambda$-cyhalothrin (D). $\mathrm{IC}_{50}$ values were determined from these graphs. $(n=5)$ 


\subsection{Reactivation studies: effect of PAM on the enzymes}

The activity of an enzyme in the control remained constant during the experiment. The reactivation percentage of the inhibited enzyme was calculated as the ratio of the recovered enzyme activity and activity in the control. For reactivation assays, only OP inhibited - enzymes were examined (OP pesticides; malathion ${ }^{\mathrm{R}}$ and dichlorvos ${ }^{\mathrm{R}}$ ). Different pesticide concentrations with CAT, SOD, and GPx solutions were prepared and incubated for $15 \mathrm{~min}$, then, two different concentrations of PAM (final concentrations of tested reactivator were 1 and $10 \mathrm{mM}$ ) were added to inhibited enzyme solutions and again incubated for $15 \mathrm{~min}$ for reactivation. Then, the activities of enzymes were measured. The reactivation percentage of the inhibited enzyme was calculated as the ratio of the recovered enzyme activity and activity in the control.

The results of the reactivation experiment show that only CAT, which is inhibited by organophosphate pesticides, can be reactivated by PAM. GPX and SOD are not reactivated by PAM. Reactivation analysis graph for CAT was drawn using activity $\%$ values (Figure 4 ). As seen in Figure 4, under the exposure of 50, 100, 200, 400, 600 and $800 \mu \mathrm{M}$ malathion concentrations, CAT activity \% was calculated as $72 ; 63 ; 38 ; 10 ; 12$ and $11 \%$, respectively. After, inhibited CAT incubated with $1 \mathrm{mM}$ PAM, CAT activity \% was calculated as $92 ; 78 ; 58$; 40; 35 and $31 \%$, respectively. When inhibited CAT incubated with $10 \mathrm{mM}$ PAM, CAT activity $\%$ was calculated as $98 ; 89 ; 72 ; 57 ; 45$ and $39 \%$, respectively.

Under the exposure of 100, 200, 400,1000, 1200 and $1500 \mu \mathrm{M}$ dichlorvos concentrations, $\%$ CAT activity were calculated as $50 ; 38 ; 22 ; 8 ; 7$ and $6 \%$, respectively. After, inhibited CAT incubated with $1 \mathrm{mM}$ PAM, CAT activity \% was calculated as $95 ; 89 ; 62 ; 40 ; 35$ and $30 \%$, respectively. When inhibited CAT incubated with $10 \mathrm{mM}$ PAM, CAT activity \% was calculated as $93 ; 90 ; 65 ; 43 ; 32$ and $28 \%$, respectively. When the results are examined, it is seen that increasing the PAM concentration does not significantly affect the reactivation percentage of the CAT enzyme.

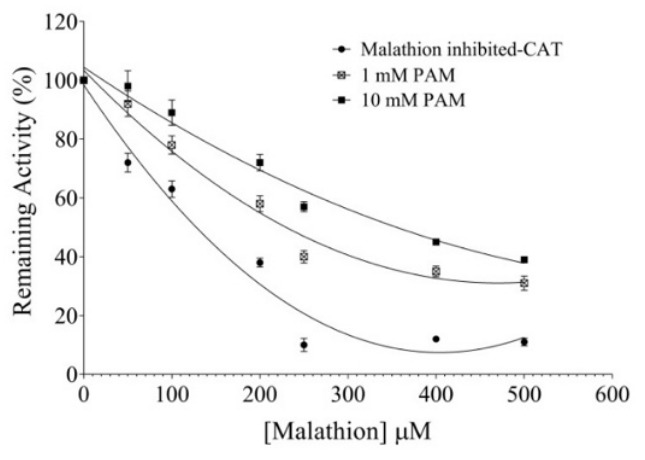

(A)

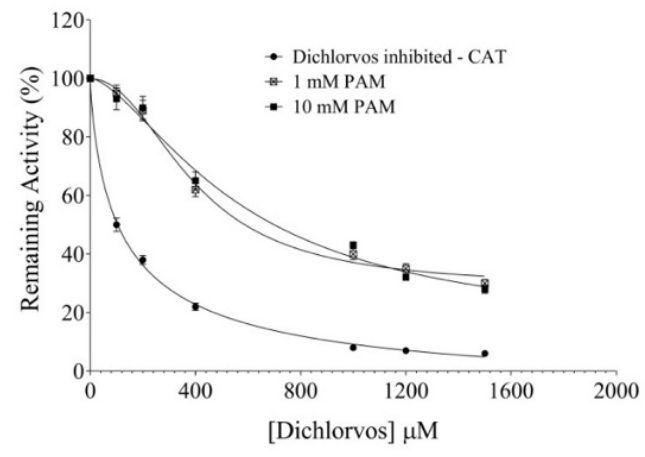

(B)

Fig. 4. Remaining Activity \% vs (A) [Malathion] and (B) [Dichlorvos] reactivation analysis graphs for CAT in the presence of $1 \mathrm{mM}$ and $10 \mathrm{mM}$ PAM

\section{Discussion}

When the results obtained in the present study were examined, the concentration range of OP pesticides (malathion and dichlorvos) inhibited CAT, SOD, and GPx enzymes were determined 
as $50-500 \mu \mathrm{M}$ and $100-1500 \mu \mathrm{M}$, respectively. For PYR pesticides (deltamethrin and $\lambda$ cyhaloethrin), this concentration range was determined as $2-40 \mu \mathrm{M}$ and $250-2250 \mu \mathrm{M}$, respectively. No change in enzyme activities was detected at low and high amounts of these pesticide concentrations (Figure 5). It was determined that deltamethrin and $\lambda$-cyhaloethrin, which are PYR class pesticides, inhibited CAT activity maximum $~ 80 \%-\sim 75 \%$, SOD activity $\sim 25 \%-\sim 40 \%$, GPx activity $\sim 85 \%-\sim 80 \%$, respectively, in the determined concentration range (Figure 5). When the $\mathrm{IC}_{50}$ values given in Table 3 are examined, it could be concluded that deltamethrin is inhibited CAT, SOD, and GPx in very low concentrations in comparison with the other pesticides.
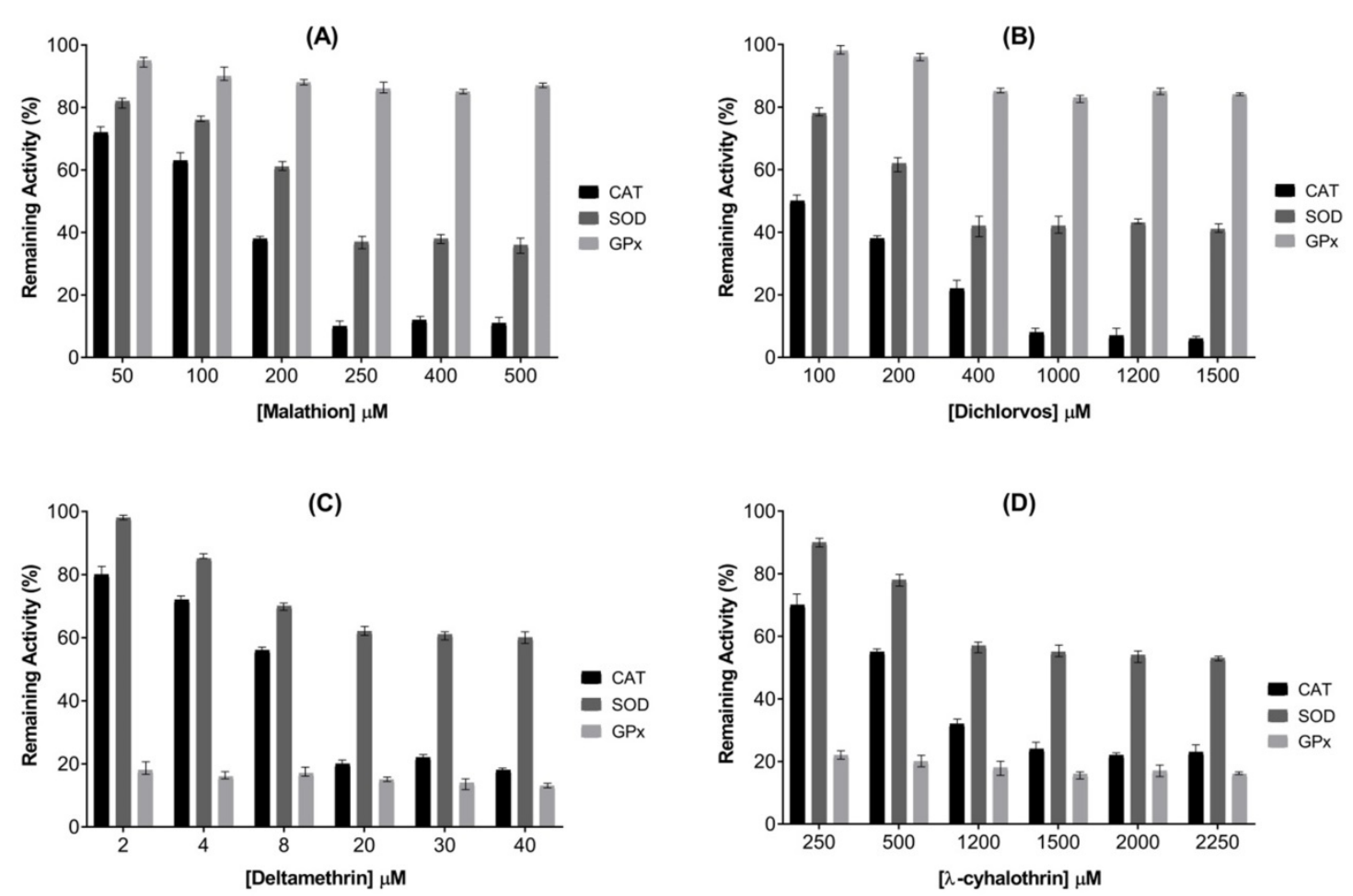

Fig. 5. Effects of malathion (A), dichlorvos (B), deltamethrin (C), $\lambda$-cyhalothrin (D) on CAT, SOD, and GPx activities $(\mathrm{n}=5)$

When the literature was examined, it was observed that the inhibition effect of pesticides as environmental pollutants was investigated on some enzymes. Al-Ghanim et al. have reported that CAT and SOD were inhibited by fenvalerate (PYR pesticide) in vivo (Al-Ghanim et al 2020). Gultekin et al. have shown the in vitro inhibition effect of chlorpyrifos - ethyl (OP pesticide) on the antioxidant enzymes; CAT, GPx, and SOD and they observed that the activity of all three enzymes was decreased significantly at low $(0.01-0.1 \mathrm{~g} / \mathrm{L})$ and high concentration (0.4-100 g/L) of chlorpyrifos-ethyl (Gultekin et. al. 2000). Sadowska-Woda et al. reported that a significant reduction in the activities of CAT was observed at all $\beta$-cyfluthrin (PYR pesticide) (43-1075 ppm) concentrations, while SOD activities were significantly decreased only in erythrocytes incubated with the highest $\beta$-cyfluthrin concentration (Sadowska-Woda et. al. 2010). Vasuki et al. reported that cypermethrin (PYR pesticide) caused a decrease in CAT 
activity and an increase in SOD activity in vivo (Vasuki et. al. 2016). Kale et al. reported that a single dose of cypermethrin (PYR pesticide) $(2500 \mathrm{mg} / \mathrm{kg}$ body wt) was administered orally to rats and increased oxidative stress resulted in an increase in the activity of antioxidant enzymes such as CAT and SOD in vivo (Kale et. al. 1999). Also, Nwamba et al. reported an in vivo study about the effect of pesticides on antioxidant enzymes and it was observed that dichlorvos (OP pesticide) (43 mg/L) increased the activity of SOD and CAT (Nwamba et. al. 2018). Decreased SOD, CAT, and GPx activity in in vitro studies may be attributed to direct damage to protein structure and increased production of $\mathrm{H}_{2} \mathrm{O}_{2}$. Similar to the results obtained in the literature studies, it was found that the OP and PYR class pesticides that we used in our study inhibited antioxidant enzymes.

When the literature was examined, it was observed that the number of in vivo studies on pesticides was higher than in vitro studies but more investigation of in vitro systems for pesticides is necessary to verify their applicability to the estimation of pesticide metabolism in live (Katagi 2020). On the other hand, in vitro enzyme activity studies with pesticides will lead to biosensor studies that can be designed for pesticide determination (Goçalves et al. 2021; Zhai et al. 2021; Paluzar et al. 2017).

On the other hand, oxime based cholinesterase reactivators such pralidoxime (2-PAM), trimedoxime (TMB-4), obidoxime (LüH-6), asoxime (HI-6), and other agents like anticonvulsants (e.g. benzodiazepine) and anticholinergics (e.g. atropine) have been used as antidotes against OP-intoxication (Worek et. al. 2020; Antonijevic et. al. 2018; Savall et. al. 2020). But, no study has yet been reported on the reactivation effect of PAM on OP inhibitedantioxidant enzymes. Considering the OP inhibition with the mentioned pesticides, the in vitro reactivation effect of PAM on OP inhibited-antioxidant enzymes was first time experimentally investigated in this present study. For this, the reactivation effect of PAM was determined for only OP inhibited-enzymes. It was found that only inhibited CAT recovered its activity with PAM, although SOD and GPx were inhibited. Reactivation results of CAT were shown in Figure 4. When the results are examined, it is seen that increasing the PAM concentration does not significantly affect the reactivation percentage of the CAT enzyme. When the results are examined, it is seen that increasing the PAM concentration does not significantly affect the reactivation percentage of CAT enzyme.

\section{Conclusion}

This work has determined activity changes of CAT, SOD, and GPx during the incubation period to OP and PYR pesticides widely used in agriculture. The results showed that deltamethrin, a PYR class pesticide, was found to be a more potent inhibitor for the antioxidant enzymes followed by the rest of the pesticides used in this study. Additionally, only CAT is reactivated by PAM against OP pesticides, dichlorvos ${ }^{\mathrm{R}}$, and malathion ${ }^{\mathrm{R}}$. In this context, the potential doses of pesticides, which can create a risk for live life, have been identified. This study showed that malathion, dichlorvos, deltamethrin, and $\lambda$-cyhalothrin pesticides are potent inhibitors for CAT, SOD, and GPx enzymes and PAM can be used as a reactivator for organophosphate inhibitedCAT enzyme. Accordingly, our findings confirmed the essential importance of conscious and 
inspected usage of pesticides. Additionally, this in vitro enzyme activity study with the pesticides will lead to biosensor studies that can be designed for pesticide determination.

\section{ACKNOWLEDGEMENTS}

The present study was financially supported by Trakya University Research Fund (Project No: TÜBAP 2012/122). We are grateful to Trakya University Research Fund for its support.

\section{References}

Aebi, H. (1984) Catalase in vitro. Methods in Enzimology. 105, 121-126.

Al-Ghanim, K.A., Mahboob, S., Vijayaraghavan, P., Al-Misned, F.A., Kim, Y.O., Kim, H.J. (2020) Sub-lethal effect of synthetic pyrethroid pesticide on metabolic enzymes and protein profile of non-target Zebra fish, Danio rerio. Saudi Journal of Biological Sciences. 27 (1), 441-447.

Antonijevic, E., Musilek, K., Kuca, K., Djukic-Cosic, D., Curcic, M., Miladonavic, D.C., Bulat, Z., Antonijevica, B. (2018) Dose-response modeling of reactivating potency of oximes K027 and K203 against a direct acetylcholinesterase inhibitor in rat erythrocytes. Food and Chemical Toxicology. 121, 224-230.

Banerjee, K., Utture, S., Dasgupta, S., Kandaswamy, C., Pradhan, S., Kulkarni, S., Adsule, P. (2012) Multiresidue determination of 375 organic contaminants including pesticides, polychlorinated biphenyls, and polyaromatic hydrocarbons in fruits and vegetables by gas chromatography-triple quadrupole mass spectrometry with the introduction of semiquantification approach Journal of Chromatograph. A. 1270, 283-295.

Becker, K., Seiwert, M., Angerer, J., Kolossa-Gehring, M., Hoppe, H.W., Ball, M., Schulz, C., Thumulla, J., Seifert, B. (2006) GerES IV Pilot Study: Assessment of the exposure of German children to organophosphorus and pyrethroid pesticides Int. J. Hyg. Environ. Health, 209 (3) 221-233.

Beutler, E. (1971) Red cell metabolism Manual of biochemical methods; Academic Press; Pp. 68. Beutler, E. Eds., London.

Cakmak, I., Marschner, H. (1992) Magnesium Deficiency and High Light Intensity Enhance Activities of Superoxide Dismutase, Ascorbate Peroxidase, and Glutathione Reductase in Bean Leaves. Plant Physiology. 98, 1222-1238.

Christine, J.W., Joseph, J.C. (2010) Measurement of superoxide dismutase, catalase and glutathione peroxidase in cultured cells and tissue. Nature Protocols 5, 51-66. 
Ciscato, C.H.P., Gebara, A.B., Spinosa, H.D.S. (2014) Pesticide residues in cow milk consumed in São Paulo City (Brasil). J. Environ. Sci. Health Part B: Pesticicdes, Food Contam., Agric. Waste 37, 323-330.

Coscollà, C., López, A., Yahyaoui, A., Colin, P., Robin, C., Poinsignon, Q., Yusa, V. (2017) Human exposure and risk assessment to airborne pesticides in a rural French community, Science of the Total Environment. 585, 856-868.

Dhindsa, R.H., Plumb-Dhindsa, R., Thorpe, T.A. (1981) Leaf Senescence: Correlated with Increased Levels of Membrane Permeability and Lipid Peroxidation, and Decreased Levels of Superoxide Dismutase and Catalase. Journal of Experimental Botany. 32, 93-101.

Eisenthal, R., Cornish, B.A. (1974) Statistical considerations in the estimation of enzyme kinetic parameters by the direct linear plot and other methods. Biochemical Journal 139 (3), 721-730.

Fernandes, V.C., Freitas, M., Pacheco, J.P.G., Oliveira, J.M., Domingues, V.F., DelerueMatos, C. (2018) Magnetic dispersive micro solid-phase extraction and gas chromatography determination of organophosphorus pesticides in strawberries. Journal of chromatography A. $1556,1-12$.

Fortes, C., Mastroeni, S., Pilla, M.A., Antonelli, G., Lunghini, L., Aprea, C. (2013) The relation between dietary habits and urinary levels of 3-phenoxybenzoic acid, a pyrethroid metabolite Food Chem. Toxicol. 52, 91-96.

Gibbs, J.L., Yost, M.G., Negrete, M., Fenske, R.A. (2017) Passive Sampling for Indoor and Outdoor Exposures to Chlorpyrifos, Azinphos-Methyl, and Oxygen Analogs in a Rural Agricultural Community. Environmental Health Perspective. 125 (3) 333-342.

Glorennec, P., Serrano, T., Fravallo, M., Warembourg, M., Monfort, C., Cordier, S., Viel, J.F., Le Gléau, F., Le Bot, F., Chevrier, C. (2017) Determinants of children's exposure to pyrethroid insecticides in western France. Environ. Int. 104, 76-82.

Gonçalves, A.M.M., Rocha, C.P., Marques, J.C., Gonçalves, F.J.M. (2021) Enzymes as useful biomarkers to assess the response of freshwater communities to pesticide exposure $-\mathrm{A}$ review. Ecological Indicators. 122, 107303.

Gultekin, F., Ozturk, M., Akdogan, M. (2000) The effect od organophosphate insecticide chlorpyrifos-ethyl on lipid peroxidation and antioxidant enzymes (in vitro) Archives of Toxicology. 74, 533-538.

Han, J., Zhou, L., Luo, M., Liang, Y., Zhao, W., Wang, P., Zhou, Z., Liu, D. (2017) Nonoccupational Exposure to Pyrethroids and Risk of Coronary Heart Disease in the Chinese Population Environmental Science \& Technology. 51, 664-670. 
Held, P. (2001) The Importance of Using the Appropriate Microplate for Absorbance Measurements in the Ultraviolet Region of the Spectrum. Application Note, BioTek Instruments, Winooski, VT.

Isık, S., Kockar, F., Ozensoy, O., Arslan, O. (2004) Differential in vitro effects of some pesticides on carbonic anhydrase activities from some freshwater and seawater fish erythrocytes Fresen. Environ. Bull. 13 (1), 25-31.

Jokanovic, M. (2001) Biotransformation of organophosphorus compounds. Toxicology. 166 (3), 139-160.

Kale, M., Rathore, N., John, S., Bhatnagar, D. (1999) Lipid peroxidative damage on pyrethroid exposure and alterations in antioxidant status in rat erythrocytes: possible involvement of reactive oxygen species. Toxicology Letters. 105 (3), 197-205.

Katagi, T. (2020) In vitro metabolism of pesticides and industrial chemicals in fish. Journal of Pesticide Science. 45(1), 1-15.

Kitagawa, D.A.S., Cavalcante, S.F.A., dePaula, R.L., Rodrigues, R.B., Bernardo, L.B., daSilva, M.C.J., daSilva, T.N., dos Santos, W.V., Granjeiro, J.M., de Almeida, J.S.F.D., Barcellos, M.C., Correa, A.B.A., França, T.C.C., Kuča, K., Simas, A.B.C. (2019) In Vitro Evaluation of Neutral Aryloximes as Reactivators for Electrophorus eel Acetylcholinesterase Inhibited by Paraoxon. Biomolecules. 9 (10), 583-598.

Kobrlova, T., Korabecnya, J., Soukup, O. (2019) Current approaches to enhancing oxime reactivator delivery into the brain. Toxicology. 423, 75-83.

Koureas, M., Tsakalof, A., Tsatsakis, A., Hadjichristodoulou, C. (2012) Systematic review of biomonitoring studies to determine the association between exposure to organophosphorus and pyrethroid insecticides and human health outcomes. Toxicology Letters. 210, 155-168.

Lowry, O.H., Rosebrough, N.J., Farra, N.J., Randall, R.J. (1951) Protein measurement with the Folin phenol reagent. The Journal of Biological Chemistry. 193(1), 265-275.

Manzoor, F., Zafar, A., Iqbal, I. (2016) Heterotermesindicola (Wasmann) (Isoptera: Rhinotermitidae) responses to extracts from three different plants. Kuwait J. Sci.43 (3), 128134.

McKone, T.E., Castorina, R., Harnly, M.E., Kubawara, Y., Eskenazi, B., Bradman, A. (2007) Merging Models and Biomonitoring Data to Characterize Sources and Pathways of Human Exposure to Organophosphorus Pesticides in the Salinas Valley of California Environ. Sci. Technol. 41 (9), 3233-3240. 
Mercier, F., Glorennec, P., Thomas, O., Bot, B.L. (2011) Organic Contamination of Settled House Dust, A Review for Exposure Assessment Purposes. Environmental Science and Technology. 45, 6716-6727.

Nwamba, H.O., Achikanu, C.E., Chukwu, G.P. (2018) The impact of dichlorvos-pesticide on African catfish clarias gariepinus. Oceanography and Fisheries. 8 (4), 555745.

Palüzar, H., Özcan, H.M. (2017) Katalaz Temelli PANI Biyosensörü ile Deltametrinin Belirlenmesi. Süleyman Demirel Üniversitesi Fen Bilimleri Enstitüsü Dergisi. 21 (2) 644-651.

Quinn, D., Topczewski, J., Yasapala, N., Lodge, A. (2017) Why is Aged Acetylcholinesterase So Difficult to Reactivate?. Molecules. 22 (9), 1464.

Sadowska-Woda, I., Wójcik, N., Karowicz-bilińska, A., Bieszczad-bedrejczuk, E. (2010) Effect of selected antioxidants in $\beta$-cyfluthrin-induced oxidative stress in human erythrocytes in vitro. Toxicology in Vitro. 24(3), 879-884.

Savall, A.S.P., Fidélis, E.M., Gutierrez, M.E.Z., Martins, B.B., Gervini, V.C., Puntel, R.L., Roos, D.H., Ávila, D.S., Pinton, S. (2020) Pre-clinical evidence of safety and protective effect of isatin and oxime derivatives against malathion-induced toxicity Basic \& Clinical Pharmacology \& Toxicology. 126, 399-409.

Snedecor, G.W., Cochran, W.G. (1980) Statistical Methods. Pp. 143. Iowa State University Press, Ames.

Soares, S., Rosado, T., Barroso, M., Vieira, D.N., Gallardo, E. (2019) Organophosphorus pesticide determination in biological specimens: bioanalytical and toxicological aspects. International Journal of Legal Medicine. 133, 1763-1784.

Sousa, S., Maia, M.L., Correira-Sá, L., Fernandes, V.C., Delerue-Matos, C., Calhau, C., Domingues, V.F. (2020) Chemistry and Toxicology Behind Insecticides and Herbicides. Volova (Eds.). Controlled Release of Pesticides for Sustainable Agriculture, Pp. 59. Springer, Cham.

Tang, W., Wang, D., Wang, J., Wu, Z., Li, L., Huang, M., Xu, S., Yan, D. (2018) Pyrethroid pesticide residues in the global environment: An overview Chemosphere. 191, 990-1007.

Tsatsakis, A.M., Tsakiris, I.N., Tzatzarakis, M.N., Agourakis, Z.B., Tutudaki, M. (2003) Three-year study of fenthion and dimethoate pesticides in olive oil from organic and conventional cultivation. Food Addit. Contam.20 (6), 553-559.

Turan, Y., Arslan, O., Kockar, F. (2002) The inhibitory effects of some pesticides on human erythrocyte carbonic anhydrase activity (in vitro). Fresen. Environ. Bull. 11 (1), 14-21 
Van den Dries, M.A., Pronk, A., Guxens, M., Spaan, S., Voortman, T., Jaddoe, V.W., Jusko, T.A., Longnecker, M.P., Tiemeier, H. (2018) Determinants of organophosphate pesticide exposure in pregnant women: A population-based cohort study in the Netherlands. Int. J. Hyg. Environ. Health. 221 (3), 489-501.

Vasuki, S., Karthi, S., Shivakumar, M.S. (2016) Effect of Cypermethrin Induced Antioxidant Enzymes Systems in Response to Melatonin Administration in Drosophila Melanogaster. Free Radicals and Antioxidants. 6 (2), 167-181.

Wongmaneepratip, W., Yang, H. (2020) Investigating the migration of pyrethroid residues between mung bean sprouts and growth media. Food Chemistry. 343, 128480.

Worek, F., Thiermann, H., Szinicz, L., Eyer, P. (2004) Kinetic analysis of interactions between human acetylcholinesterase, structurally different organophosphorus compounds and oximes. Biochem. Pharmacol. 68 (11), 2237-2248.

Worek, F., Thiermann, H., Wille, T. (2020) Organophosphorus compounds and oximes: a critical review. Archives of Toxicology. 94, 2275-2292.

Zhai, R., Chen, G., Liu, G., Huang, X., Xu, X.M., Li, L., Zhang, Y., Wang, J., Jin, M., Xu, D., Abd El-Aty, A.M. (2021) Enzyme inhibition methods based on Au nanomaterials for rapid detection of organophosphorus pesticides in agricultural and environmental samples: A review. Journal of Advanced Research. https://doi.org/10.1016/j.jare.2021.08.008.

Submitted: $\quad 12 / 01 / 2021$

Revised: $\quad 31 / 01 / 2021$

Accepted: $\quad$ 15/09/2021

DOI: $\quad 10.48129 / \mathrm{kjs} .11847$ 